\title{
Shared Obligations and the Responsibility of an International Organization and Its Member States
}

\section{The Case of EU Mixed Agreements}

\author{
Nataša Nedeski \\ Assistant Professor of Public International Law, University of Amsterdam, \\ Amsterdam, The Netherlands \\ n.nedeski@uva.nl
}

\begin{abstract}
Discussions on the allocation of international responsibility between an international organization and its member states do not comprehensively engage with the role of obligations in assigning responsibility to the organization and/or its members. The present article sets out what will be termed an obligations-based approach to the allocation of international responsibility by exploring the phenomenon of sharing international obligations by an international organization and its members, as well as the implications thereof for their responsibility under international law. It will do so by focusing on the practice of concluding mixed agreements by the EU and its member states, which commonly results in overlapping obligations for the organization and its members. It is ultimately argued that a distinction should be made between two types of shared obligations in mixed agreements in order to untangle who can be held responsible in case of a breach: the EU, the member state(s), or both.
\end{abstract}

\section{Keywords}

shared obligations - shared responsibility - allocation of responsibility - mixed agreements - European Union - International Law Commission 
It has long been recognised that international organizations are autonomous actors possessing a legal personality separate from their members. At the same time, states retain their separate legal identity when they become members of an international organization. This is of particular relevance to questions of international responsibility, as the distinct legal personality of an international organization and its member states entails that all of them possess the capacity to bear international obligations and to incur international responsibility when those obligations are breached. However, notwithstanding their respective separate identities, the relationship between an organization and its members is typically characterised by a high degree of interconnectedness. ${ }^{1}$ It is because of the complex relationship between an organization and its members that questions on the allocation of international responsibility are bound to ensue in any legal scenario involving international organizations: Does a breach of an international obligation give rise to the responsibility of the organization, its members, or all of them? These questions are relevant not only for the organization and member states that are bound by the obligation in question, but also for injured parties that may wish to claim cessation or reparation.

The allocation of international responsibility between an international organization and its member states has received considerable attention in academic debate. Discussions on this topic have consistently taken place within the general contours established by the law of international responsibility. In the Articles on the Responsibility of States for Internationally Wrongful Acts (ARSIWA) and the Articles on the Responsibility of International Organizations $(\mathrm{ARIO})^{2}$ it is set out that responsibility for an internationally wrongful act is contingent on the presence of two elements: attribution of conduct and

* This article draws from and further builds upon the author's PhD research; see N. Nedeski, Shared obligations in international law (PhD thesis, University of Amsterdam 2017).

1 Ana Sofia Barros, Cedric Ryngaert and Jan Wouters, 'Member States, International Organizations and International Responsibility: Exploring a Legal Triangle' (2015) 12 International Organizations Law Review 285, p. 285.

2 While the ARIO do not enjoy the same level of authority as the ILC'S Articles on the Responsibility of States for Internationally Wrongful Acts (which are considered, to a large extent, to be a reflection of customary international law), there is no equally or more authoritative starting point for an analysis that involves the responsibility of an international organization. See André Nollkaemper, 'Introduction' in André Nollkaemper and Ilias Plakokefalos (eds), Principles of Shared Responsibility in International Law (CUP, 2014) p. 3. 
breach of an international obligation. ${ }^{3}$ Many scholars place the element of attribution at the center of their analysis, ${ }^{4}$ but do not comprehensively engage with the role of obligations in assigning responsibility to the organization and/ or its members.

The present article contributes to the debate on the allocation of responsibility by exploring the phenomenon of sharing international obligations by an organization and its members, as well as the implications thereof for their responsibility under international law. It sets out what will be termed an obligations-based approach to the allocation of international responsibility, with the element of breach of an international obligation situated at the center of the analysis. It is argued that a more systematic approach to the nature of obligations that bind an international organization and its members offers a fruitful avenue for allocating responsibility, as it can help untangle who can be held internationally responsible in case of a breach. While fruitful, it is an avenue that has remained largely unexplored in existing scholarship. A notable exception includes the work of the International Law Commission's Special Rapporteur, Giorgio Gaja. In his reports on the responsibility of international organizations, Gaja has suggested that cases in which "both the organization and its members have jointly undertaken the same obligation towards a third party and the obligation is breached" will result in the responsibility of both the organization and its members for the same internationally wrongful act. ${ }^{5}$ While this approach can (and will) be critiqued for being overly broad, ${ }^{6}$ it reflects the main idea underlying this article, namely that the sharing of international obligations by an organization and its members can have relevant implications for responsibility relations.

\subsection{The case of EU mixed agreements}

The focus of the present analysis lies on the practice of concluding mixed agreements by the European Union and its member states. ${ }^{7}$ Since under EU

3 Article 4 ARIO; Article 2 ARSIWA. See Brigitte Stern, 'The Elements of an Internationally Wrongful Act' in James Crawford, Alain Pellet and Simon Olleson (eds), The Law of International Responsibility (OUP 2010).

4 See for instance Cedric Ryngaert, "The Responsibility of Member States of International Organizations: Concluding Observations' (2015) 12 International Organizations Law Review 502 , p. 507. In his discussion of various scholarly contributions, he identifies "the centrality of attribution" as a key theme permeating analyses on the issue of allocating responsibility.

5 Giorgio Gaja, 'Sixth Report on the Responsibility of International Organizations' (2008) (A/CN.4/597 23), para 24 .

6 See section 3 below.

7 Mixed agreements have been defined as "any treaty to which an international organization, some or all of its Member States and one or more third State are parties and for the execution 
law the competence to legislate and adopt legally binding acts with regard to certain fields of activity is divided between the organization and its members, the subject matter of a particular treaty can fall partly within the competence of the EU and partly within that of the member states. ${ }^{8}$ Due to this sharing of sovereign powers between the organization and its members, the conclusion of mixed agreements has become "the predominant form of EU participation in major international treaties", ${ }^{\prime}$ with examples including the WTO Agreement; the Kyoto Protocol; the Barcelona Convention for the Protection of the Mediterranean Sea Against Pollution and the Convention on the Rights of Persons with Disabilities. As is further discussed in section 2, the conclusion of mixed agreements commonly results in overlapping obligations of the organization and its members. Accordingly, the case of EU mixed agreements constitutes the ideal case-study for an analysis of shared obligations and the allocation of international responsibility between an organization and its members.

In the event of a breach of a mixed agreement on the part of the EU and/or its member states, the question arises who can be held internationally responsible for what. This question has been the subject of heated debate over the span of multiple decades. It should be noted that many scholars have attempted to grapple with the so-called 'special features' of the EU in their analyses, ${ }^{10}$ while at the same time remaining within the general contours established by the law of international responsibility. An approach to EU and member state responsibility that is commonly found in legal literature focuses primarily on the element of attribution of conduct in assigning international responsibility, discussing for example whether the division of competences or the exercise of

of which neither the organization nor its Member States have full competence". Henry G Schermers, 'A Typology of Mixed Agreements' in David O'Keeffe and Henry G Schermers (eds), Mixed Agreements (Kluwer Law \& Taxation Publishers and the Europa Instituut, 1983) $25^{-26 .}$

8 Joni Heliskoski, Mixed Agreements as a Technique for Organizing the International Relations of the European Community and Its Member States (Kluwer Law International 2001) 121.

9 Esa Paasivirta, 'The Responsibility of Member States of International Organizations? A Special Case for the European Union' (2015) 12 International Organizations Law Review 448, p. $45^{\circ}$.

10 For example, Esa Paasivirta and Pieter-Jan Kuijper, 'Does One Size Fit All?: The European Community and the Responsibility of International Organizations' (2005) 36 Netherlands Yearbook of International Law 169; Stefan Talmon, 'Responsibility of International Organizations: Does the European Community Require Special Treatment?' in Maurizio Ragazzi (ed), International Responsibility Today: Essays in Memory of Oscar Schachter (Martinus Nijhoff, 2005); Paolo Palchetti, 'Unique, Special or Simply a Primus Inter Pares? The European Union in International Law' (2018) 29 European Journal of International Law 1409 . 
normative control by the EU forms (or should form) the basis for attribution of conduct and hence the allocation of international responsibility. ${ }^{11}$ This discussion follows from the European Commission's insistence on a special rule of attribution of conduct during the codification of the ARIO. This special rule was opposed by Special Rapporteur Gaja but eventually resulted in the adoption of Article 64 ARIO on lex specialis, which has left open the possibility of the existence or future development of such special rules. ${ }^{12}$

The present analysis proceeds from the presumption that no special rules govern the allocation of international responsibility for breaches of mixed agreements to the EU and its members. Indeed, various commentators have come to the conclusion that under international law "there is no special rule of attribution applicable to the EU or at least not yet", ${ }^{13}$ whether on the basis of normative control or on the basis of the division of competences. This means that the topic of allocating responsibility to the EU and/or its member is governed by the general rules of international responsibility. Hence, the value of the present analysis is not limited to the context of the EU since it can be extended to general questions of responsibility for breaches of international obligations shared by other international organizations and their members.

Against this background, this contribution argues for a different take on the topic by focusing primarily on the element of breach of an international obligation. Where the majority of the discussion on the allocation of responsibility for mixed agreements adopts either a competence-based approach or engages

11 For example, Paasivirta and Kuijper (supra note 10); Frank Hoffmeister, 'Litigating against the European Union and Its Member States - Who Responds under the ILC's Draft Articles on International Responsibility of International Organizations?' (2010) 21 European Journal of International Law 723; Joni Heliskoski, 'EU Declarations of Competence and International Responsibility' in Malcolm Evans and Panos Koutrakos (eds), The International Responsibility of the European Union: European and International Perspectives (Hart Publishing, 2013); Andrés Delgado Casteleiro, The International Responsibility of the European Union (CUP, 2016); Gracia Marín Durán, 'Untangling the International Responsibility of the European Union and Its Member States in the World Trade Organization Post-Lisbon: A Competence/ Remedy Model' (2017) 28 European Journal of International Law. It should be noted, however, that all of these authors recognize that responsibility only arises if the actor(s) in question are bound by an international obligation, but do not foresee any further role for obligations in determining responsibility.

12 Durán (n 11) 706.

13 Palchetti, (n 10) 1423, who analyzes various recent contributions to the literature on this topic. See also Cristina Contartese, 'Competence-Based Approach, Normative Control and the International Responsibility of the EU and Its Member States' (2019) 19 International Organizations Law Review 339, 377. After an analysis of recent case-law she concludes that this body of case-law is "far from suggesting the emergence of a customary norm on this special rule of attribution." 
with the normative control doctrine, ${ }^{14}$ this article further explores the merits of an obligations-based approach to the allocation of international responsibility. In this respect, it is interesting to note that in the specific context of EU mixed agreements, several scholars have engaged with the potential role of obligations in allocating international responsibility to the EU and/or its member states, and appear to have recognized the idea of sharing international obligations in some shape or form. However, as is further explored in section 3 , current approaches tend to oversimplify the implications of sharing obligations for international responsibility and are in need of further refinement.

In exploring this obligations-based approach to the allocation of responsibility, it is ultimately argued that a distinction should be made between two types of shared obligations in mixed agreements in order to untangle who can be held internationally responsible in case of a breach: the EU, the member state(s), or both. The main claim put forward is that the nature of the obligation breached can directly inform who is responsible for a breach of that obligation, and can clarify what injured parties can claim from whom. In some instances, the sharing of international obligations automatically results in the shared responsibility of both the EU and its members, depending on whether the shared obligation breached is divisible or indivisible.

\section{$1.2 \quad$ The concept of shared responsibility}

Considering that this article explores the relationship between the sharing of international obligations and the sharing of international responsibility for wrongful acts by the organization and its members, some preliminary remarks on the concept of shared responsibility are in order. Where independent responsibility presupposes that a single state or international organization is exclusively responsible for its own internationally wrongful act that independently produces a particular harmful outcome ${ }^{15}$ shared responsibility arises when multiple states and/or international organizations contribute to a single harmful outcome by committing one or more internationally wrongful acts. ${ }^{16}$ In such cases multiple states and/or international organizations can be held responsible in for contributing to a single harmful outcome, and the question 'who can be held responsible for what' is brought to the forefront. In particular, the assertion that multiple states and/or international organizations share international responsibility has relevant implications for the content of

\footnotetext{
14 For a recent analysis of these two approaches see Contartese (n 13).

15 André Nollkaemper and Dov Jacobs, 'Shared Responsibility in International Law: A Conceptual Framework' (2013) 34 Michigan Journal of International Law 359, p. 381.

16 Nollkaemper (n 2) 6-11.
} 
that responsibility, since the ensuing obligations of cessation and reparation may also become shared by the plurality of responsible actors, ${ }^{17}$ and an injured party may claim cessation or reparation from each of them.

The notion of shared responsibility includes situations where an international organization and one or more of its members jointly commit the same wrongful act. This is a situation explicitly recognized in Article 48 ARIO, which provides that, "[W]here an international organization and one or more States or other international organizations are responsible for the same internationally wrongful act, the responsibility of each State or organization may be invoked in relation to that act."

The 'sameness' of a wrongful act signifies that there is only one internationally wrongful act that is committed by a plurality of actors, and the International Law Commission has noted that this covers situations in which "a single course of conduct is at the same time attributable to several States and is internationally wrongful for each of them". ${ }^{18}$ However, it should be underlined that shared responsibility is not limited to situations where multiple actors commit the same wrongful act. It also includes situations where an international organization and its member states contribute to a single harmful outcome through separate internationally wrongful conduct, ${ }^{19}$ in which case they share responsibility for multiple internationally wrongful acts. At first sight the distinction between these two manifestations of shared responsibility might appear quite abstract, but as will be seen in section 4, it can have concrete implications for what injured parties may claim from whom.

\subsection{Structure}

Against this background, this article sets out a systematic approach to the nature of obligations in mixed agreements and shows how this can helps untangle who can be held internationally responsible in case of a breach: the EU, the member states, or both. The ensuing analysis consists of three steps.

First, section 2 introduces the notion of shared obligations and discusses how the practice of concluding mixed agreements can result in overlapping

17 See André Nollkaemper et al, 'Guiding Principles on Shared Responsibility in International Law' (2020) 31 European Journal of International Law, 15.

18 On multiple attribution of a single course of conduct giving rise to responsibility for the same wrongful act see International Law Commission, 'Draft Articles on Responsibility of States for Internationally Wrongful Acts, with Commentaries' (2001) (A/56/10 124) (hereafter: 'ARSIWA with commentaries'); International Law Commission, 'Draft Articles on the Responsibility of International Organizations, with Commentaries' (2010) (A/66/10 16) (hereafter: 'ARIO with commentaries').

19 ARSIWA with commentaries (n 18) 125. 
obligations of both the EU and its member states. As a result of this overlap various questions arise: Which of them is bound to do what, and who can be held internationally responsible for what in case of a breach? Section 3 shows that the potential overlap between the obligations of the EU and its members has not remained unnoticed in legal literature, with a number of authors engaging with an obligations-based approach to the allocation of responsibility for mixed agreements. However, the two main views on the role of obligations in allocating responsibility that can be deduced from legal literature tend to oversimplify the issue at hand and are in need of further refinement. Section 4 argues that such refinement can be provided by a further categorization of shared obligations. It ultimately aims to show how the categorization of a shared obligation as either 'divisible' or 'indivisible' can function as an important tool in allocating responsibility for breaches of mixed agreements.

The performance of an international obligation is not always up to only one state or international organization. The concept of shared obligations reflects the idea that performing obligations does not always occur in a vacuum, and captures situations where multiple states and/or international organizations are connected in the performance of an international obligation. Such a connection is present when 1) two or more states or international organizations are bound to a similar international obligation that 2) pertains to the same constellation of facts. These two elements combined indicate that there is an overlap between the obligations of multiple states and/or international organizations, with the result that they are connected in the performance of that obligation. It is contended that it is this connection between the bearers of a shared obligation that brings questions regarding performance and international responsibility to the forefront: Who is bound to do what, and who can be held responsible for what in case of a breach?

These questions have been raised regularly in the context of mixed agreements, and for good reason. This section shows that the practice of concluding mixed agreements makes it rather likely for the EU and its members to share their international obligations. First, the practice of concluding mixed agreements - which as we know is induced by the sharing of sovereign powers - commonly results in both the EU and its members being bound to a similar international obligation (section 2.1). Second, due to the fact that the area over which those sovereign powers are exercised by the EU and its member states generally overlap, it becomes more likely for each of their (similar) obligations 
to pertain to the same constellation of facts resulting, essentially, in overlapping obligations (section 2.2).

\subsection{Mixed agreements and 'multiple bearers of a similar international obligation'}

The notion of shared obligations presupposes, first of all, that the EU and one or more of its member states are bearers of a similar international obligation. After all, one state or international organization cannot 'share' an international obligation on its own. The obligations incumbent on both the EU and its member states are similar when they have similar normative content, for instance if they prescribe similar conduct (for example an obligation to take measures to prevent pollution) or the achievement of a similar result (for example an obligation to pay a certain amount of financial assistance to a particular state). When it comes to the question who bears a particular obligation, it should be noted that throughout this article the bindingness of obligations is approached from the outside perspective of general international law rather than from within an organization's institutional order. ${ }^{20}$

International obligations that solely bind the EU do not constitute shared obligations. For instance, if the EU independently concludes a bilateral fisheries access agreement with a state, it will be the $\mathrm{EU}$ (and not its member states) that is bound to the obligations enshrined in that agreement. This was confirmed by the International Tribunal for the Law of the Sea in its 2015 Advisory Opinion on Case No 27, in which it was asked to consider who could be held responsible for breaches of such agreements: the organization and/or its members. The Tribunal considered that if the international organization is the only contracting party to a bilateral fisheries access agreement with another state, the organization will be the one bound to obligations in that agreement, including the obligation to "ensure that vessels flying the flag of a member State comply with the fisheries laws and regulations of the [coastal State]."21 Such obligations bind only the organization and are not shared with its members, with the consequence that only the organization can be held responsible for breaches of obligations under these agreements. Indeed, the Tribunal

20 Proceeding from the assumption that there is a distinction between general international law and international institutional law, as in Catherine Brölmann, The Institutional Veil in Public International Law (Hart Publishing, 2007) 12-13. Within the EU legal order, Member States are bound by agreements concluded by the EU even if they are not themselves parties to that international agreement, see Article 216(2) TFEU.

21 Request for an Advisory Opinion submitted by the Sub-Regional Fisheries Commission, Case No 21, 2 April 2015, International Tribunal for the Law of the Sea, Advisory Opinion, ITLOS Reports 2015, p 4, para 172. 
considered that in cases where member states engage in conduct that violates the coastal state's fisheries laws and regulations, the organization can be held responsible if it did not comply with its (due diligence) obligation to ensure compliance. ${ }^{22}$

Mixed agreements differ from the bilateral agreements such as those assessed in Case No 21 on an essential point, since they are characterised by the fact that both the EU and its members are parties. Does this mean that the EU and its member always bear the same international obligations under a mixed agreement? In principle, when an organization and its members become parties to the same international agreement, the general starting point in international law is that all of them are bound to the treaty as a whole, following from the international law principle pacta sunt servanda. ${ }^{23}$ This would indeed entail that, as parties to a mixed agreement, the $\mathrm{EU}$ and its member states become bearers of the full range of obligations enshrined in that treaty.

However, it is precisely this general starting point that has been the topic of debate in the context of mixed agreements, the main discussion being whether the division of competences between the EU and its members has implications for the external allocation of international obligations. The question then becomes whether such a division of competences - which, after all, is based on the internal rules of the organization - is opposable against third parties that are not members of the European Union. According to the European Commission, the answer to this question would be a definitive yes. In its comments addressed to the ILC during the drafting of the ARIO, the European Commission articulated its position that the allocation of obligations between the EU and its member states should in principle be determined by the 'rules of the organization' and hence by the division of competences. ${ }^{24}$ According to

22 Ibid, at para 168; Paolo Palchetti, "The Allocation of International Responsibility in the Context of Investor-State Dispute Settlement Mechanisms Established by EU International Agreements' (2017) 28 European Business Law Review 185, 193. "In this kind of situation, the conduct triggering responsibility is the failure by the organization to comply with its due diligence obligation".

23 This principle is codified in Article 26 VCLT (1969) and Article 26 VCLT (1986). See Anthony Aust, 'Pacta Sunt Servanda', Max Planck Encyclopedia of Public International Law [MPEPIL] (2007) para. $1<$ www.mpepil.com>; Casteleiro, supra note 11, p 35 .

24 'Comments and observations received from international organizations', Fifty-sixth session of the International Law Commission (2004) (A/CN.4/545), p 26. See also Paasivirta and Kuijper (n 10) 216, who observe that "for the Community the 'rules of the organization' do not just determine whether acts by certain organs are properly to be regarded as acts of the organization, but also who is to be regarded as being capable of assuming the international obligation in question (...) From a Community perspective the question of apportionment [of obligations] is really the primary question and attribution the secondary one." 
the Commission's position the rules of the organization would be key to determining whether "the obligation of which a breach is alleged is an obligation of the organization in question." ${ }^{25}$ If one were to follow this line of reasoning, the number of situations in which the EU and its members are bound to similar international obligations would be drastically reduced.

The prevailing view in legal scholarship on the matter, however, is more nuanced in that it does not accept that the division of competences is necessarily determinative for the allocation of obligations under international law. A distinction can be made between two situations. First, in cases where the division of competences is clearly disclosed to the other parties to the mixed agreement, for instance by attaching a declaration of competences to the agreement, it is generally accepted that the $\mathrm{EU}$ and its member states are each bound to the part of the agreement for which they have competence. ${ }^{26}$ After all, by becoming parties to a mixed agreement that includes a competence clause, third parties consent to a division of obligations based on the division of competences between the EU and its members. ${ }^{27}$ In concreto, this could mean that any international obligation that falls within an area of exclusive EU competence would be binding upon the EU only; and hence would not bind its members vis-à-vis third states.

The Swordfish case has been credited as an example of a situation "where the division of competence was indeed mirrored in the scope of external obligation". 28 This case concerned vessels flying under the Spanish flag that had been fishing for swordfish on the high seas adjacent to Chile's exclusive economic zone, which Chile alleged had caused a decline in swordfish stocks in

\section{Ibid, 13.}

26 Christian Tomuschat, 'Liability for Mixed Agreements' in David O'Keeffe and Henry G Schermers (eds), Mixed Agreements (Kluwer Law \& Taxation Publishers and the Europa Instituut, 1983), p. 127; Giorgio Gaja, 'The European Community's Rights and Obligations under Mixed Agreements' in David O'Keeffe and Henry G Schermers (eds), Mixed Agreements (Kluwer Law \& Taxation Publishers and the Europa Instituut, 1983), pp. 133134; Moshe Hirsch, The Responsibility of International Organizations Toward Third Parties (Martinus Nijhoff Publishers 1995) 24; Marise Cremona, 'External Relations of the EU and the Member States: Competence, Mixed Agreements, International Responsibility, and Effects of International Law' EUI Working Paper LAW No. 2006/22, p. 21; Mirka Möldner, 'European Community and Union, Mixed Agreements', Max Planck Encyclopedia of Public International Law [MPEPIL] (2011), para. $35<$ www.mpepil.com>.

27 Christiane Ahlborn, 'The Rules of International Organizations and the Law of International Responsibility' (2011) 8 International Organizations Law Review 397, 463.

28 André Nollkaemper, 'Joint Responsibility between the EU and Member States for NonPerformance of Obligations under Multilateral Environmental Agreements' in Elisa Morgera (ed), The External Environmental Policy of the European Union (CUP, 2012). 
contravention to the UN Convention on the Law of the Sea. ${ }^{29}$ Even though both the EU and Spain are parties to the Convention, Chile opted to institute proceedings solely against the EU. It is certainly conceivable that it chose to do so because the conservation of marine biological resources under the common fisheries policy is an exclusive EU competence, something which was clearly communicated by the EU upon ratification to the other parties to the Convention. ${ }^{30}$

If we then turn to cases where the division of competences is not clearly disclosed to non-EU member state parties to the treaty, there appears to be no reason to depart from the general starting point in international law that the EU and its members are bound to all of the provisions in the agreement to which they have become parties. This indeed appears to be the prevailing view in academic literature ${ }^{31}$ following not only from the principle pacta sunt servanda but also that of good faith, which is "[o]ne of the basic principles governing the creation and performance of legal obligations". ${ }^{32}$ From a public international law perspective it is also relevant to underline that the division of competences between the EU and its members derives from the Treaties of the European Union, which is res inter alios acta for third states and, in accordance with the pacta tertiis principle, cannot be opposed to third parties in the absence of their consent. ${ }^{33}$

29 United Nations Convention on the Law of the Sea (1982) 1833 UNTS 3.

30 Declaration concerning the competence of the European Community with regard to matters governed by the United Nations Convention on the Law of the Sea of 10 December 1982 and the Agreement of 28 July 1994 relating to the implementation of Part XI of the Convention.

31 Emilija Leinarte, 'The Principle of Independent Responsibility of the European Union and Its Member States in the International Economic Context' (2018) 21 Journal of International Economic Law 171, p. 19o; Durán (n 12) p. 704; Andrés Delgado Casteleiro and Joris Larik, 'The "Odd Couple": The Responsibility of the EU at the WTO' in Malcolm Evans and Panos Koutrakos (eds), The International Responsibility of the European Union: European and International Perspectives (Hart Publishing, 2013) 238; Nollkaemper, supra note 28; Möldner (n 26) para 35; Talmon (n 10) pp. 416-417; Martin Björklund, 'Responsibility in the EC for Mixed Agreements - Should Non-Member Parties Care?' (2001) 7o Nordic Journal of International Law 373, p. 373 .

32 See 'Advies Inzake Extern Optreden van de Europese Unie En Internationaal Recht, Commissie van Advies Inzake Volkenrechtelijke Vraagstukken (Advisory Committee on Issues of Public International Law)' (2014) Advies nr. 24. The principle of good faith, moreover, forms an integral part of the pacta sunt servanda rule, see Gabčikovo-Nagymaros Project (Hungary/Slovakia), International Court of Justice, Judgment, ICJ Reports 1997, p 7 para 114, 142.

33 See generally Malgosia Fitzmaurice, 'Third Parties and the Law of Treaties' (2002) 6 Max Planck Yearbook of United Nations Law 37. See also Ahlborn (n 27) 463. 
The view that the EU and its members are bound to all obligations in a mixed agreement in the absence of a clear disclosure of competences to third parties finds support in practice. On several occasions the Court of Justice of the European Union (CJEU) itself appears to have taken this position. ${ }^{34}$ For example, it implied that both the EU and France were bound to the obligation to strictly limit pollution from land-based sources in lake Etang de Berre, ${ }^{35}$ which emanated from article 6(1) of the Athens Protocol to the Barcelona Convention for the Protection of the Mediterranean Sea Against Pollution. In another case the CJEU found that "in the absence of derogations expressly laid down" in the Lomé Convention, the EU and its member states were "jointly liable (...) for the fulfilment of every obligation arising from [the Convention]", ${ }^{36}$ which included the obligation to provide 12.000 million ECU in financial assistance to the African, Caribbean and Pacific group of states in a five-year period.

A comparable position can be derived from WTO case-law. ${ }^{37}$ For example in Computer Equipment, the Panel rejected the European Commission's competence-based approach to the allocation of obligations and found that " $\mathrm{t}]$ he European Communities, Ireland and the United Kingdom are all bound by their tariff commitments under Schedule LXXX". ${ }^{38}$ Moreover, in the Large Civil Aircraft case instituted against the EU and four of its member states, the Panel considered that " $[\mathrm{e}]$ ach of these five is, in its own right, a Member of the WTO, with all the rights and obligations pertaining to such membership."39

Based on the above it can be concluded that mixed agreements commonly give rise to similar international obligations for the $\mathrm{EU}$ and its member states, except in the case that the division of competences has been clearly communicated to the other parties and one or more of the obligations in that agreement fall solely within the competence of the EU or the member states. In this respect, a small caveat is in order. While the disclosure of competences might occur in various ways, the division of competences "is one of the most complex and debated issues in EU external relations law" and is subject to continuous change and evolution. ${ }^{40}$ It is not uncommon for declarations of competence

\footnotetext{
34 As noted by Paasivirta and Kuijper (n 10) 187; Leinarte (n 31) 187.

35 Case C-239/o3, Commission v French Republic [2004] ECR I-9325, para. 26; Hoffmeister, (n 11) 744 .

36 Case C-316/91, European Parliament v Council of the European Union [1994] ECR I-oo625, para 29 .

37 For an overview see Leinarte, (n 31) pp 186-187.

38 WTO, Panel Reports, Cases WT/DS62/AB/R; WT/DS67/AB/R; WT/DS68/AB/R; EC-Customs Classification of Certain Computer Equipment, para 8.16.

39 WTO, Panel Report, Case WT/DS316/R, European Communities and Certain Member States - Measures Affecting Trade in Large Civil Aircraft, para 7.174.

40 Casteleiro (n 11$) 111$.
} 
issued by the EU to be "imprecise, incomplete and open-ended", ${ }^{41}$ and the EU updating its declarations of competence seems to be a rare occurrence. Therefore, the mere fact that a declaration of competence has been issued does not necessarily mean that the division of competences between the EU and its member states has been clearly communicated to third parties. This only adds to the possibility that both the EU and its members become bound to similar international obligations as a result of the conclusion of mixed agreements.

\subsection{Mixed agreements and obligations 'pertaining to the same constellation of facts'}

The connection between the bearers of a shared obligations consists of more than simply being bound to an obligation with the same normative content. Indeed, the mere fact that an international organization and its member states are bound to an obligation with the same normative content does not as such entail that they are connected in the performance of that obligation. When an international organization and its member share an international obligation there is another element at play that is indicative of this connection: The obligation of the organization and its members pertains to the same constellation of facts.

This element is essential to the idea of sharing international obligations, as it indicates that the concept of shared obligations is not to be equated with the full catalogue of obligations that arise from a multilateral rule or source and are consequently binding on a plurality of actors. After all, such obligations may bind multiple states or international organizations, but as long as those obligations do not pertain to the same constellation of facts they are simply not 'shared'. This can be clearly illustrated by the following example. While all states parties to the Vienna Convention on Diplomatic Relations - a multilateral treaty - may be bearers of the same obligation to take measures to protect diplomatic premises, in principle each state's obligation pertains only to those diplomatic premises that are situated in its own territory. Because each of their obligations pertain to a different constellation of facts (i.e. different premises on different territories), their obligations require a purely individualized performance and quite simply do not overlap.

Thus, the final step in determining whether a particular obligation arising from a mixed agreement is shared consists of enquiring whether the similar obligations of the EU and its members pertain to the same constellation of facts, which would result in an overlap of their obligations. All in all, there are two ways in which such an overlap of obligations is typically brought about.

$41 \quad$ Heliskoski (n 11) 202. 
The EU and its member states agree to an obligation to work towards or achieve a common goal

First, an overlap between obligations can be the result of the EU and its member states agreeing ex ante to a similar international obligation to work towards or achieve a common goal. Clear examples of such obligations is a mixed agreement include the obligation of Iceland, the EU and its member states to achieve a 20 per cent reduction of their aggregate greenhouse gas emissions by 2020 in the second commitment period of the Kyoto Protocol ${ }^{42}$ and the obligation of the EU and its member states to provide 12.000 million ECU in financial assistance to the ACP states. ${ }^{43}$ In both of these examples the bearers of the obligation in question have themselves agreed explicitly to a concrete common goal (respectively a common greenhouse gas emissions reduction target and the making available of a predetermined amount of monetary assets), consequently bringing about that the obligations of each of them pertain to the same constellation of facts.

2.2 .2

The EU and its member states are legally or factually linked to a common situation

Moreover, overlapping obligations can be the result of the existence of a legal or factual link between the EU and its member states on the one hand and the same territory or individual on the other hand. When it comes to a wide range of international obligations, the link between a state or international organization and a particular territory or individual is determinative of what constellation of facts its obligations apply to. In many cases this entails that the obligations of different duty-bearers do not overlap. Imagine, for example, that state $\mathrm{X}$ is party to a multilateral human rights treaty. State X's human rights obligations pertain to those individuals within its territory or control, and in principle do not pertain to individuals in state Y. Similarly, a state's obligation to take measures to prevent transboundary harm pertains only to activities taking place in its own territory. Finally, multiple states may be parties to a multilateral trade treaty, but state A's obligation to afford a certain import tariff to specific imported products pertains only to those products imported into its own territory. In principle its obligations do not pertain to products that are imported by state B, another party to the same treaty.

42 Conference of the Parties serving as the meeting of the Parties to the Kyoto Protocol, 'Report on Its Seventh Session' (2011) (FCCC/KP/CMP/2011/10/Add.1).

43 Peter-Tobias Stoll, 'Lomé Conventions', Max Planck Encyclopedia of Public International Law, Volume II (1997); Parliament v Council (n 36). 
In some circumstances a link may be established between multiple states and the same territory or individual, resulting in overlapping obligations of multiple duty-bearers in cases where they simultaneously exercise sovereignty, authority or control. An example outside the context of mixed agreements can be two states occupying the territory of another state, such as the joint occupation of Iraq by the US and the UK, ${ }^{44}$ in which case the obligation to prevent the looting of natural resources of on both states pertains to the territory of Iraq. Another example includes the exercise of control by both Australia and Nauru over a refugee detention center, 45 in which case the obligation to prevent torture of both states pertains to the same constellation of facts. An example of overlapping obligations of an international organization and a state is the duty of care in relation to civilian personnel deployed abroad, incumbent on both the sending international organization and the host state. ${ }^{46}$

In the same vein, it is possible for there to be a link between both the EU and one or more member states and the same territory or individual. What is more, the sharing of sovereignty that is inherent to the relationship between the EU and its members is an important factor contributing to the likelihood that their obligations pertain to the same constellation of facts. This is due to the following. When the EU becomes bound to an international obligation, in many instances it incurs that obligation with regard to the combined territory of its member states, whereas each individual member state's obligations in principle pertains solely to its own territory or control. This necessarily results in an overlap of the obligations of the EU and each of its member states. This is aptly illustrated by the following two factual scenarios involving the obligations of the EU and one or more of its members, which have both been the subject of international adjudication.

44 Stefan Talmon, 'A Plurality of Responsible Actors: International Responsibility for Acts of the Coalition Provisional Authority in Iraq' in P Shiner and A Williams (eds), The Iraq War and International Law (Hart Publishing, 2008) 3.

45 Niels Frenzen, 'Extraterritorial Refugee Protection' in André Nollkaemper and Ilias Plakokefalos (eds), The Practice of Shared Responsibility in International Law (CUP 2017) 17; Madeline Gleeson, 'Offshore Processing and Australia's Responsibility for Asylum Seekers and Refugees in Nauru and Papua New Guinea' (Andrew \& Renata Kaldor Centre for International Refugee Law, UNSW, 2015) 4.

46 Lorenzo Gasbarri, 'Overlapping Responsibility: The Legal Relationship Between the International Organization and the Host State' in Andrea de Guttry and others (eds), The Duty of Care of International Organizations Towards Their Civilian Personnel (TMC Asser Press, 2018); Andrea Spagnolo, 'The Duty of Care of International Organizations: Issues of Conduct and Responsibility Attribution' in Andrea de Guttry and others (eds), The Duty of Care of International Organizations Towards Their Civilian Personnel (TMC Asser Press, 2018). 
The first example concerns the overlapping obligations of the EU and France in relation to the pollution of a salt-water lake in France, which was the subject of the Etang de Berre case before the CJEU. The European Commission had instituted infringement proceedings against France because it believed that France had failed to fulfil the obligation to strictly limit pollution from land-based sources; an obligation that arises from article 6(1) of the Athens Protocol (to which both the EU and some of its members are parties). The CJEU considered that the European Commission was entitled to institute such proceedings against France to ensure that it would comply with this obligation because the EU itself "had assumed responsibility for the due performance of the agreement". 4

The factual scenario that is the subject of this case is easily construed as a situation of overlapping obligations. Both France and the EU are bound to an obligation with similar normative content that pertains to the same constellation of facts: namely to the lake Etang de Berre on French territory. After all, France's obligation to strictly limit pollution pertains to land-based sources within its territory, and the EU's similar obligation to strictly limit pollution pertains to land-based sources within the territory of its member states (including France). It should be noted that in this particular scenario France's obligation only overlaps with that of the EU and does not overlap with those of the other member states parties to the Athens Protocol since, for instance, Spain's obligation to strictly limit pollution does not pertain to land-based sources on French territory. Accordingly, the obligation in this particular constellation of facts is shared solely by France and the EU.

Another example concerns the obligations of the United Kingdom, Ireland and the EU pertaining to the import of certain products addressed by a WTO Panel in the Computer Equipment case. In this case, the United States argued that customs authorities in the UK and Ireland had violated Article II GATT which, in combination with Schedule LXXX, gives rise to an obligation to afford a particular tariff to Local Area Network (LAN) equipment imported from the US. The Panel considered that Ireland, the UK and the EU were all bound to this obligation. ${ }^{48}$ Since the notion of shared obligations presupposes not only that multiple legal persons are bound to a similar obligation but also that their obligations overlap, the next question to ask would be what constellation of facts each of their obligations pertain to.

The answer to this question produces a similar picture of overlapping obligations as the one painted with regard to the obligations in the Etang de Berre

47 Commission v. French Republic (n 35) para 26.

48 Certain Computer Equipment (n 38$)$. 
case. The UK is under an obligation to grant tariff concessions to LAN equipment imported into its own territory but it is under no obligation that such tariff concessions are granted when products are imported into Ireland, and vice versa. The $\mathrm{EU}$, however, incurs the obligation with regard to the import of products throughout the entire EU, including the UK and Ireland. Accordingly, the EU and the UK share the obligation to afford a particular tariff to LAN equipment imported into the UK, whereas the EU and Ireland share the obligation to afford a particular tariff to LAN equipment imported into Ireland.

\subsection{Interim conclusion}

The above analysis shows that the practice of concluding mixed agreements can result in the sharing of obligations by the EU and one or more member states, where all of them are bound to an obligation with similar normative content that pertains to the same constellation of facts. It is this overlap between the obligations of the EU and member state(s) that connects them in the performance of their obligations. As a result of this overlap various questions arise: which of them is bound to do what and who can be held internationally responsible for what in case of a breach? Against this background, the next section explores the way in which the implications of sharing obligations by the EU and its members have been approached in legal literature.

\section{3}

Exploring the Obligations-Based Approach to the Allocation of Responsibility: A Need for Further Refinement

The potential overlap between the obligations of the EU and its members has not remained unnoticed. An examination of existing literature quickly reveals that various scholars have at least recognized the idea of sharing international obligations in mixed agreements in some shape or form. A number of scholars have attempted to engage with what will be called an obligations-based approach to allocating responsibility for mixed agreements, which addresses the potential implications of the EU and its members being bound to 'joint obligations' or 'the same obligations' for the allocation of international responsibility. This section briefly assesses the two main views on to the role of obligations in allocating responsibility for mixed agreements that can be deduced from legal literature, in light of the notion of shared obligations set out in this article.

Overall, the analysis aims to show that current discussions on the obligations-based approach tend to oversimplify the issue at hand and are in need of further refinement. First, current discussions do not properly capture 
situations where the EU and its members share an international obligation, but rather proceed from an understanding of 'joint obligations' that is quite simply too broad. Second, each of the two (fundamentally opposing) views on the obligations-based approach comes to a too rigorous conclusion: either being bound to a joint obligation results in shared responsibility of the EU and its members all of the time, or it does not have any implications for shared responsibility. Thus, while various scholars may have dealt with the idea of sharing obligations in the context of mixed agreements, they have not yet managed to adequately address the implications of sharing obligations for the allocation of responsibility.

\section{1 $\quad$ The strategy of joint obligations}

The strategy of joint obligations essentially comes down to the argument that since, under international law, mixed agreements impose obligations that are 'joint' or 'the same' on both the EU and its members, any breach of that agreement results in some form of joint responsibility under international law. ${ }^{49}$ Overall, minimal explanation is offered for such far-reaching implications of being bound to the same obligation, other than that it is the result of the fact that the EU's obligations are not separated from those of the member states ${ }^{50}$ and should be regarded as an "undivided whole". ${ }^{51}$

This approach to the role of obligations in determining responsibility for mixed agreements finds support in the work of ILC Special Rapporteur (SR) Giorgio Gaja on the responsibility of international organizations. In his second report, he explores various potential bases for the joint responsibility of an organization together with one or more of its members. This analysis begins with a discussion of dual attribution of conduct as a basis for responsibility of an organization and its members, but eventually notes that joint, or joint and several, responsibility does not necessarily depend on dual attribution of conduct. ${ }^{52}$ Mixed agreements are discussed as the only example, and the SR stipulates that in case of a breach of a mixed agreement that does not distinguish

49 See for example, Talmon (n 10) pp. 416-417; Rafael Leal-Arcas, 'The European Community and Mixed Agreements' (2001) European Foreign Affairs Review 483, p. 497; Eric Stein, 'External Relations of the European Community: Structure and Process' Collected Courses of the Academy of European Law (1991).

50 Eleftheria Neframi, 'International Responsibility of the European Community and of the Member States under Mixed Agreements' in Enzo Cannizaro (ed), The European Union as an Actor in International Relations (Kluwer Law International, 2002) p 201.

$5^{1} \quad$ Gaja (n 26) p 137.

$5^{2}$ Giorgio Gaja, 'Second Report on the Responsibility of International Organizations' (2004) (A/CN.4/541) p. 5, para. 8. 
between the respective obligations of the $\mathrm{EU}$ and its member states, joint responsibility will ensue. ${ }^{53}$

While the SR does not employ the terminology of joint (or shared) obligations, his argumentation similarly comes down to the claim that being bound to the same international obligation is enough to make an international organization and its members per se jointly responsible. ${ }^{54}$ In one of his later reports, the SR again alludes to this argument when discussing an early version of what is now article 48 ARIO, which addresses situations where "an international organization and one or more States or other international organizations are responsible for the same internationally wrongful act". In his analysis of this provision, the case in which "both the organization and its members have jointly undertaken the same obligation towards a third party and the obligation is breached" 55 is put forward as an example of shared responsibility for the same internationally wrongful act, accompanied by a footnote that explicitly refers to mixed agreements where the obligations of the EU and member states "have not been separated". 56

All in all, the strategy of joint obligations supports the idea that an overlap between the obligations of the EU and its members can have relevant implications for the allocation of responsibility for breaches of mixed agreements. However, the understanding of when such an overlap of obligations occurs is quite simply too broad and in need of further refinement. Unlike the notion of shared obligations introduced in section 2, the strategy of joint obligations suggests that being bound to an obligation with similar normative content in and of itself would merit the automatic consequence of shared responsibility. ${ }^{57}$

Adopting such an approach would essentially amount to attaching the consequence of shared responsibility to the full catalogue of international obligations arising from multilateral treaties and customary international law. After all, any multilateral treaty or customary norm gives rise obligations with the same content for a plurality of legal persons. However, in this piece it has been contended that being bound to the same obligation is not enough to qualify

\footnotetext{
53 Ibid.

54 Delgado Casteleiro (n 11) p 64.

55 Gaja (n 6) p 23, para 24.

56 Ibid, p. 23, footnote 31.

57 For an exception see Nollkaemper (n 28). He notes that a distinction should be made between "situations where the EU and Member States are bound by the same agreement, on the one hand, and where they are bound by joint obligations (...) since in the latter case joint responsibility for non-performance is implied", but without providing a comprehensive definition of such 'joint obligations'.
} 
those obligations as shared obligations. ${ }^{58}$ Only if those same obligations of the EU and its members pertain to the same constellation of facts will they be connected in the performance of that obligation, which may have implications for the allocation of responsibility.

\subsection{The strategy of disconnecting international responsibility from the nature of obligations}

The strategy of joint obligations has been rightly critiqued, with several scholars asserting that the mere fact that obligations in a mixed agreement are not apportioned amongst the EU and member states is not enough to justify the automatic consequence of joint responsibility of the EU and its member states. ${ }^{59}$ Interestingly, however, this assertion is generally where the analysis of the role of obligations in determining responsibility for breaches of mixed agreements ends. ${ }^{60}$ Hence, where the strategy of joint obligations envisages a crucial role for the nature of obligations in the allocation of responsibility for mixed agreements, the only other approach that may be discerned from legal literature completely disconnects international responsibility from the nature of the obligations breached. In other words, the latter approach does not seem to envisage any role for obligations in allocating responsibility.

The apparent assumption that the nature of obligations is not particularly relevant in the context of mixed agreements is displayed in the way some scholars have analyzed the case of Parliament v. Council, which concerns the obligation to provide 12.00o ECU in financial assistance to the African, Caribbean and Pacific group of states (ACP states) arising from the Fourth Lomé Convention. ${ }^{61}$ In this case, the European Parliament argued that the obligation in question was binding only on the (then) EC. However, the CJEU considered that "[i]n the absence of derogations expressly laid down in the Convention, the Community and its Member States as partners of the ACP States were jointly liable to those latter states for the fulfilment of every obligation arising from the commitments undertaken, including those relating to financial assistance." 62

58 Compare James Crawford, 'Multilateral Rights and Obligations in International Law' (2006) 319 Recueil des Cours 325, p. 344, who argues that a finding "[t]hat State A's rights or obligations have the same content so far as States B, C, D... are concerned does not necessarily make those rights or obligations multilateral."

59 Durán (n 11) p 704; Leinarte (n 31); Casteleiro and Larik (n 31) p 238; Casteleiro (n 11) p 66.

6o See for example, Casteleiro and Larik (n 31 ) p 238; Casteleiro (n 11) p 66; Armin Steinbach, $E U$ Liability and International Economic Law (Hart Publishing, 2017) p. 143.

61 Parliament $v$ Council (n 36$)$.

62 Ibid, para 29. 
The above passage is commonly referred to in support of the strategy of joint obligations. ${ }^{63}$ Those opposing this interpretation, however, have construed several arguments to underline that the CJEU'S pronouncement on this point should not be taken to imply that all international obligations incumbent upon both the EU and the member states inherently give rise to joint responsibility. For example, Paasivirta and Kuijper suggest that the joint responsibility envisaged in this case was due to the specific nature of the treaty in question. The Lomé Convention was concluded between the Union and the states 'of the one part' and the ACP states 'of the other part', and should therefore be qualified as a 'bilateral mixed agreement' concluded between two 'sides' (with each side consisting of multiple legal persons). ${ }^{64}$ By establishing the joint responsibility of the EU and member states, the argument goes, the CJEU was not making general claims about joint responsibility but was rather acknowledging the bilateral nature of the Lomé Convention. ${ }^{65}$

Several objections to this interpretation come to mind. In any case, the added value of a fusion between the established categories of bilateral and multilateral treaties raises several questions, particularly if one considers that under international law a treaty concluded between more than two legal persons is simply considered to be a multilateral one $e^{66}$ and, moreover, the qualification of a treaty as bilateral or multilateral does not necessarily mean that all of the legal relations established by that treaty are bilateral or multilateral. ${ }^{67}$ The most compelling objection to this interpretation, however, is formulated by Paasivirta and Kuijper themselves, who ponder the implications of applying their own reasoning to the ACP States that make up the other 'side' of the treaty: would those states be jointly responsible for any breach of the human rights obligations arising from the Lomé Convention, even if committed independently by one of those states on its own territory? As concluded by the

63 Gaja (n 52) p 5, para. 8; Neframi (n 5o) p 201, fn 28; Heliskoski (n 11) p 148.

64 Paasivirta and Kuijper (n 10) p 188; Pieter Jan Kuijper and Esa Paasivirta, 'EU International Responsibility and Its Attribution: From the Inside Looking Out' in Malcolm Evans and Panos Koutrakos (eds), The International Responsibility of the European Union: European and International Perspectives (Hart Publishing, 2013), p. 64. See also the comments made by the European Commission to the ILC in the context of its work on the responsibility of international organizations, 'Comments and observations received from international organizations', Fifty-sixth session of the International Law Commission (2004) (A/CN.4/545), p. 32 para. 22. This argument has been repeated by several scholars, see for instance Contartese, supra note 13, p. 346.

65 Casteleiro (n 11) p 65; Casteleiro and Larik (n 31) p 237; Kuijper and Paasivirta (n 64) p 64; Paasivirta and Kuijper (n 10) p 188.

66 Crawford (n 47) 338-339, who explicitly addresses treaties concluded by a group of states 'of the one part' and another group 'of the other part'.

67 Crawford (n 58$)$ p 344. 
authors, "one can hardly imagine". 68 This intuition is confirmed if one attempts to place such obligations within the framework of shared obligations: assuming that the human rights obligations of each of the ACP states would pertain to different constellations of facts (i.e. to individuals within each of their respective territories or control), in principle there would be no overlap of obligations to even give rise to questions of shared responsibility.

A more convincing interpretation of the contested passage in Parliament $v$. Council is that the CJEU was simply talking about the binding character of the obligations arising from the Lomé Convention. ${ }^{69}$ Even though the CJEU'S use of the term 'liable' at first glance might suggest it was talking about the question of responsibility for a breach of obligation, the CJEU specifically referred to the EU and its member states as being jointly liable for the fulfilment of obligations (rather than for a breach of obligations). From this it can be inferred that the CJEU intended to convey that the EU and its member states were all bound to the obligations in the agreement, which is supported by the corresponding conclusion that 'the obligation to grant the Community's financial assistance falls on the Community and on its Member States, considered together.'

This takes us back to the main argument of those opposing the strategy of joint obligations, namely that being bound to the same obligation does not as such give rise to joint responsibility in case of a breach. While this is certainly true, it is unfortunate that this is where the analysis of the potential implications of sharing international obligations ends. It is contended that those who rightly critique the strategy of joint obligations have at the same time inadvertently passed on the opportunity to further refine the obligations-based approach to allocating responsibility. After all, in cases where the similar obligations of the EU and its member state(s) overlap, this overlap may very well have relevant implications for the allocation of international responsibility. The next section argues that such implications can be unraveled on the basis of a further categorization of shared obligations.

\section{$4 \quad$ Refining the Obligations-Based Approach to the Allocation of Responsibility: Distinguishing Between Divisible and Indivisible Shared Obligations}

While the notion of shared obligations set out in section 2 above reveals that the EU and its members can be connected in the performance of various

68 Paasivirta and Kuijper (n 10) p 188.

69 Casteleiro and Larik (n 31) p 237. See also Leinarte (n 31) pp. 187-188, who stipulates that the CJEU appears to conflate the concepts of joint obligations and joint responsibility. 
obligations that arise from mixed agreements, such a finding does not necessarily clarify how responsibility is to be allocated when those obligations are breached. It can even be said that - rather than answering questions - the notion of shared obligations brings questions on the allocation of responsibility to the forefront: Does a breach of a shared obligation result in the responsibility of all of its bearers, with the consequence that injured parties can claim reparation or cessation from both the EU and its member states?

This section advocates for a more systematic approach to the nature of obligations that are shared by both the EU and its members, and aims to show how the categorization of a shared obligation as either 'divisible' or 'indivisible' can function as an important tool in allocating responsibility for breaches of mixed agreements. This is presented as an alternative to existing views on the role of obligations in mixed agreements, which either assume that the EU and its members always incur shared responsibility when they are bound to joint obligations, or imply that the sharing of obligations can never be enough to justify the result of shared responsibility.

In order to set out this obligations-based approach to the allocation of responsibility, the section starts by introducing the distinction between indivisible and divisible shared obligations (4.1), which is then applied to various examples of shared obligations in mixed agreements (4.2). It subsequently addresses the implications of this categorization of shared obligations for the determination of shared responsibility (4.3) and the content of shared responsibility (4.4).

\subsection{Introducing the distinction between indivisible and divisible shared obligations}

A shared obligation is indivisible when it binds multiple states and/or international organizations to achieve a common performance..$^{70}$ A hypothetical example would be an international organization and multiple members states binding themselves to an obligation to reduce their combined tuna catches with 20 per cent before the year 2020. In such a case, all of them are bound to

70 Compare the category of 'solidary' or 'joint and several' obligations that is known in many domestic legal systems. In domestic private law the main characteristic of such a solidary obligation is that each of its bearers is bound to perform the whole obligation; its performance cannot be divided. See The Commission on European Contract Law, Principles of European Contract Law: Part III (Ole Lando and others eds, Kluwer Law International 2003); Christian von Bar and Eric Clive, Principles, Definitions and Model Rules of European Private Law: Draft Common Frame of Reference (DCFR), Full Edition (Selier European Law Publishers, 20og); UNIDROIT Principles of International Commercial Contracts, with commentaries 2016, <https://www.unidroit.org/instruments/commercial-contracts/unidroit-principles-2016>. 
achieve a common performance, namely the reduction of their aggregate tuna catches with a predetermined percentage.

When multiple states and/or international organizations are bound to a divisible shared obligation, ${ }^{71}$ each of them is bound only to its own share. For instance, one may think of a situation where states A, B and C are under an obligation to take measures to prevent an impending genocide that is bound to take place on the territory of a neighboring state. These three states are bound to a similar international obligation that pertains to the same constellation of facts, resulting in overlapping obligations. However, they are not bound to achieve a common performance. Instead, each of them is bound to do its own share by taking measures that are within its power with the aim of preventing genocide.

Essentially, each of these two categories is characterised by a distinct structure of performance. On the one hand, an indivisible shared obligation can only be fulfilled or breached by all of its bearers simultaneously. This is a logical consequence of the fact that all of them are bound to achieve a common performance, such as the above-mentioned 20 per cent reduction of combined tuna catches by 2020 . As soon as this common performance has been achieved, the obligation is fulfilled by all duty-bearers. However, if that common performance is not achieved by 2020 the obligation is simultaneously breached by all of its bearers. It is not possible for an indivisible shared obligation to be fulfilled by one of its bearers while another simultaneously breaches that obligation; it is either fulfilled by all of them or breached by all of them.

On the other hand, a divisible shared obligation has a divisible structure of performance. This means that it is possible for a duty-bearer to independently breach or fulfil the obligation in question. It would be perfectly possible for state $\mathrm{A}$ to take the measures that are required of it, thereby doing its share and fulfilling the obligation to prevent genocide, while states B and C fail to take the necessary measures and thereby breach the obligation to prevent genocide. A bearer of a divisible shared obligation is released from the obligation as soon as it has done its own share, regardless of whether other duty-bearers have done theirs.

It will be seen below that this categorisation of obligations can easily be applied to obligations in mixed agreements that are shared by the EU and its members. After a brief discussion on how to qualify shared obligations in mixed agreements as divisible or indivisible, it will be assessed how the distinct

71 Compare the category of 'divided' or 'separate' obligations that is known in many domestic private law systems. See ibid. 
structure of performance of each of these two categories of shared obligations can have relevant implications for responsibility relations.

\subsection{Qualifying shared obligations in mixed agreements as divisible or indivisible}

All in all, qualifying a particular shared obligation that arises from a mixed agreement as divisible or indivisible calls for a determination of the content of that obligation: What does it ask of its bearers? Does it oblige the EU together with one or more of its members to achieve a common result, or is each of them bound to do only its own share?

It is submitted that answering this question can be facilitated by relying on the distinction between obligations of result and obligations of conduct. Where an obligation of result requires that its bearer(s) successfully achieve a specific result, ${ }^{72}$ an obligation of conduct is a best efforts obligation ${ }^{73}$ that requires its bearers to do all in their power in pursuance of a particular result, but without ultimately committing them to achieve the result. ${ }^{74}$ In the case that the EU and its members are bound to a shared obligation, qualifying that obligation as one of conduct or result indicates to a large extent whether the shared obligation in question is divisible or indivisible.

Since an indivisible shared obligation requires its bearers to achieve (rather than merely pursue) a common performance, a shared obligation can be indivisible only if it is an obligation of result. A clear example of an indivisible shared obligation arising from a mixed agreement is the obligation of the EU and its member states, together with Iceland, to reduce their aggregate greenhouse gas emissions with 20 per cent by 2020 in the second commitment period of the Kyoto Protocol. All bearers of this obligation are bound to achieve a common result, namely a 20 per cent reduction of their combined emissions within a predetermined period..$^{75}$ Other examples of indivisible shared obligations that require the $\mathrm{EU}$ and one or more of its members to achieve a common result are the obligation of the UK and the EU to afford a particular tariff to

72 Constantin P Economides, 'Content of the Obligation: Obligations of Means and Obligations of Result' in J Crawford, A Pellet and S Olleson (eds), The Law of International Responsibility (OUP, 2010) p 377 .

73 James Crawford, State Responsibility: The General Part (CUP, 2013) p 231.

74 James Crawford, 'Second Report on State Responsibility' (1999) (A/CN.4/498), p. 25; Pierre-Marie Dupuy, 'Reviewing the Difficulties of Codification: On Ago's Classification of Obligations of Means and Obligations of Result in Relation to State Responsibility' [1999] European Journal of International Law 371, p. 378.

75 However, see section 4.3.1 below, where the lex specialis pertaining to responsibility in article 4(6) Kyoto Protocol is discussed. 
LAN equipment imported into UK territory and the obligation of the EU and its member states to provide 12.000 million ECU in financial assistance to the ACP states.

In the case that a shared obligation is an obligation of conduct, it is inherently divisible. This is due to the fact that an obligation of conduct is a best efforts obligation ${ }^{76}$ that, when incumbent on multiple states or international organizations, can be said to bind each of them to their own share. Indeed, each state or organization that bears such an obligation would be obliged to take all measures that are within its power in pursuance of a particular result. As is inherent to obligations of best efforts, the specific measures that must to be taken in order to fulfil the obligation differ depending on the specific circumstances of the case and the capabilities of each duty-bearer.

An example of a divisible shared obligation arising from a mixed agreement is the obligation "to pursue limitation or reduction of emissions of greenhouse gases not controlled by the Montreal Protocol from aviation and marine bunker fuels, working through the International Civil Aviation Organization and the International Maritime Organization, respectively" arising from article 2(2) Kyoto Protocol. This obligation does not prescribe the achievement of a common result but is an obligation of conduct that requires each of its bearers to take measures in pursuance of a common result, thereby binding them only to their own share.

Another example can be found in the overlapping obligations of France and the EU to strictly limit pollution from land-based sources into lake Etang de Berre. It is worth noting that during these infringement proceedings instituted by the Commission against France, the nature of this obligation was actually a point of contention. ${ }^{77}$ On the one hand, the Commission maintained that the obligation was one of result, which in the context of our present analysis would mean that the shared obligation incumbent upon France and the EU would be qualified as indivisible. In such a case, both the EU and its member state would be bound to achieve a common result: the strict limitation of pollution from land-based sources into lake Etang de Berre. France, however, argued that the obligation in question was one of conduct, which would oblige France and the EU to take all measures in their power without having to achieve the result of a strict limitation of pollution.

${ }_{76}$ Crawford (n 74) p 231; Philippe Gautier, 'On the Classification of Obligations in International Law' in Holger P Hestermeyer (ed), Coexistence, Cooperation and Solidarity: Liber Amoricum Rüdiger Wolfrum, Volume I (Martinus Nijhoff, 2012) p 856.

77 Pieter-Jan Kuijper, 'Case C-239/o3, Commission v. French Republic' (2005) 43 Common Market Law Review 1491, p 1498. 
While the CJEU did not explicitly choose one position over the other, it did consider that article 6(1) of the Athens Protocol gives rise to a "particularly rigorous obligation" to strictly limit pollution from land-based sources, and to do so by taking "appropriate measures". ${ }^{78}$ The terminology of 'appropriate measures' employed here suggests that the obligation concerned is one of conduct that binds each of its bearers to its own share: The EU and France each have to take those measures that are within their power in pursuance of the result of strictly limiting pollution from land-based sources. This indicates that the obligation in question requires each if them to do their own share (by taking appropriate measures), and can in principle be performed by each of them independently. ${ }^{79}$

\subsection{Determining international responsibility for breaches of mixed agreements}

The categorization of a shared obligation as either indivisible or divisible functions as an important tool in untangling who can be held responsible under international law for breaches of mixed agreements.

4.3.1 Indivisible shared obligations and shared responsibility

The indivisible structure of performance of an indivisible shared obligation has far-reaching implications for the allocation of international responsibility. It is submitted that a breach of an obligation that binds the EU and one or more of its members to achieve a common result always gives rise to the shared responsibility of all of them for a single internationally wrongful act. This conclusion can be drawn by simply proceeding from the rules of international responsibility which, as we may recall, require the presence of two elements for any determination of responsibility: a breach of an international obligation and attribution of conduct.

First, international responsibility is contingent on the breach of an international obligation. Since an indivisible shared obligation binds the EU and one or more of its members to achieve a common result, the failure to achieve that result necessarily constitutes a breach by all of them. Hence, if the common result of providing 12.000 million ECU in financial assistance to the ACP states is not achieved, the EU and its member states will all be deemed to have breached the obligation to provide that amount in financial assistance which is incumbent on all of them. Moreover, if both EU and UK are bound to the

78 Commission $v$. French Republic (n 35) para 5 o.

79 However, this does not mean they will not be obliged to interact with one another, see section 4.3 .2 below. 
obligation that computer equipment imported into the UK is afforded a particular, pre-negotiated tariff, and that tariff is not afforded, the common result required by the obligation is not achieved. As a consequence, both the EU and the UK will be deemed to have breached this obligation.

Second, international responsibility requires that conduct in breach of an international obligation is attributable to one or more state(s) or international organization(s). It has already been noted that the conduct in breach of an indivisible shared obligation consists of a failure to achieve the common result that is required by the obligation. But how do we assess to whom can this failure can be attributed?

Essentially the rules on the attribution of conduct serve to determine who is the author of a particular course of conduct from the perspective of international law. In situations where the conduct in breach of a particular obligation consists of an omission, ${ }^{80}$ as is the case with breaches of indivisible shared obligations, the rules of attribution of conduct "operate at a greater level of abstraction" 81 when compared to the attribution of active conduct. By its very nature, a failure of a state or international organization to achieve a result that was required of it by a particular obligation qualifies as conduct of that state or organization. ${ }^{82}$ As a consequence, in the case of a failure to act, the element of attribution of conduct is always satisfied by identifying who was under an obligation to act in the concrete case at hand. ${ }^{83}$

With this in mind it can be inferred that an omission consisting of a failure to achieve a common result can be attributed to multiple legal persons in the case that multiple legal persons were bound to achieve that common result. This indicates that there is an inherent connection between a breach of an indivisible shared obligation in a mixed agreement (which obliges the EU and one or more of its members to achieve a common result) and multiple attribution of conduct to all bearers of the obligation. Accordingly, the failure to provide 12.000 million ECU in financial assistance to the ACP states constitutes a

8o See Crawford (n 73) p 218, defining omissions as "the failure to do what should be done".

81 Franck Latty, 'Actions and Omissions' in James Crawford, Alain Pellet and Simon Olleson (eds), The Law of International Responsibility (OUP, 2010) p 361.

82 Miles Jackson, Complicity in International Law (OUP, 2015) p 195: "by its very nature a failure on the part of the state to fulfil a positive obligation is conduct of that state. All of the legwork in such a case is done in determining the specific content of the specific obligation to take action and whether it was discharged."

83 See Pierre d'Argent, 'State Organs Placed at the Disposal of the UN, Effective Control, Wrongful Abstention and Dual Attribution of Conduct' (2014) 1 Questions of International Law, p 17. 
joint failure that is attributable to those that were bound to achieve that result in the first place: the EU and its member states. Hence, a breach of the indivisible shared obligation to provide 12.000 million ECU in financial assistance gives rise to the shared responsibility of both the EU and its members for the same wrongful act. The same can be said with regard to the failure to afford a particular tariff to LAN equipment imported into the UK: as both the EU and the UK are bound to an obligation to achieve this common result, the failure to achieve it is a joint failure that can be attributed to them both.

The same reasoning can be applied in case of a breach of the obligation to achieve a 20 per cent reduction of aggregate greenhouse gas emissions by 2020 , which is incumbent on the EU, its member states and Iceland. A failure to achieve this common result would be attributable to all bearers of the obligation and, in principle, give rise to shared responsibility of all of them for the same wrongful act. Yet, it should be noted that in this particular case such a conclusion would be precluded by the lex specialis in article 4(6) Kyoto Protocol, which instead establishes that each member state shall be responsible only for its own level of emissions, both individually and together with the EU. The fact that this provision was drafted to fit the specific situation of the $\mathrm{EU}^{84}$ suggests that negotiators were aware of the possibility that a failure to achieve their combined target would result in the shared responsibility of the $\mathrm{EU}$, its member states and Iceland.

All in all, it follows from the above that a breach of an indivisible shared obligation necessarily gives rise to the international responsibility of all duty-bearers for the same internationally wrongful act. ${ }^{85}$ Accordingly, being bound to an indivisible shared obligation is sufficient as such to give rise to shared responsibility of both the EU and its member state(s) when that obligation is breached.

4.3.2 Divisible shared obligations and shared responsibility?

Divisible shared obligations do not have such automatic consequences. Their divisible structure of performance brings with it that the determination of responsibility is more diffuse.

84 Javier de Cendra de Larragán, 'Liability of Member States and the EU in View of the International Climate Change Framework: Between Solidarity and Responsibility' in Michael Faure and Marjan Peeters (eds) Climate Change Liability (Edward Elgar Publishing, 2011) p 62.

85 On multiple attribution of a single course of conduct giving rise to responsibility for the same wrongful act (see $\mathrm{n} 18$ ). 
First, a breach of a divisible shared obligation does not necessarily constitute a breach by all of its bearers. Because such an obligation binds each duty-bearer to its own share only, it is possible for only one or some of those that bear the obligation to breach it while others fulfil the obligation. Second, whether or not conduct that breaches a divisible shared obligation can be attributed to one or more bearers of the obligation depends on the factual circumstances that are specific to each case of a breach.

Let us take as an example the divisible shared obligation of the EU and France to take appropriate measures to strictly limit pollution from landbased sources into lake Etang de Berre. With regard to this obligation several scenarios of breach and attribution of conduct can be envisaged. First, it would be possible that the EU takes all appropriate measures while France takes little to no measures at all. If one proceeds from the above-mentioned proposition that a failure to act can be attributed to the state or organization that was bound to perform those acts in the concrete case at hand, the failure to take measures in this scenario would be attributable to France only. France's omission cannot be attributed to the EU, since the obligation of the EU extends only to the measures that need to be taken by the EU itself and does not oblige the EU, for instance, that France takes appropriate measures in pursuit of the strict limitation of pollution. Accordingly, in this scenario the EU has fulfilled its obligation by taking appropriate measures whereas France has failed to take such measures, resulting in the international responsibility of France only.

One could also imagine a different scenario in which neither the EU nor France take any measures, thereby both breaching their divisible shared obligation by failing to do their share. These breaches represent individual failures of France and the EU that are attributable to each of them separately. In such a scenario the respective failures of both of them would result in shared responsibility for multiple internationally wrongful acts, considering that each of their respective failures contribute to the pollution of lake Etang de Berre.

It should be emphasised, however, that even though each bearer of a divisible shared obligation is bound only to its own share, they may still be obliged to engage with one another and failing to do so could constitute a breach of that obligation. For instance, in our example both the EU and France are bound to take those measures that are within their power to strictly limit pollution of lake Etang de Berre. Engaging with the co-bearers of a shared obligation could very well be part of the measures that are within the power of an individual duty-bearer and are hence required to fulfil that obligation. In such a case it would be bound to try, with the means reasonably available to it (e.g. through diplomatic channels), to induce other duty-bearers to take measures 
in pursuance of the common goal they are all pursuing before an individual duty-bearer can be deemed to have performed its share of the obligation. ${ }^{86}$

This is particularly relevant when an international organization and one or more of its member(s) share international obligations. After all, due to the close relationship between an organization and its members, international organizations have various means at their disposal to influence member state conduct (and vice versa). For instance, the EU has the power to institute infringement proceedings against its member state(s), which it may employ to induce its member states to comply with a particular (shared) obligation. ${ }^{87}$ Interestingly the Etang de Berre case before the CJEU was itself a manifestation of the EU taking such measures within its power, as it had instituted infringement proceedings against France with the purpose of inducing the latter to comply with the international obligation that it shared with the EU.88 It could be argued that failing to do so would have constituted a breach of the EU's share of the obligation to take measures to limit pollution from land-based sources into lake Etang de Berre.

To summarize, the sharing of a divisible obligation by the EU and its members indicates that they are connected in the performance of that obligation and may have to take measures to influence each other's conduct with the aim of inducing others to comply with the obligations that they share. However, whether or not a breach of a divisible shared obligation gives rise to shared responsibility (or rather gives rise to the responsibility of only one duty-bearer) ultimately depends on the facts of each case, since it is still possible for only one duty-bearer to fail to do its share whereas the others fulfil the obligation.

86 Compare the considerations of the Arbitral Tribunal in Eurotunnel regarding the (non-) performance of obligations pertaining to the Coquelles terminal that were incumbent upon both France and the United Kingdom, taking into account that "the record ... though it sometimes shows disagreement between [France and the United Kingdom], does not show a consistent and conscientious opposition by the United Kingdom to a unilateral French policy, such that the United Kingdom could argue that it did everything within its power to bring a clearly unsatisfactory situation promptly to an end." Eurotunnel Arbitration (The Channel Tunnel Group Ltd \& France-Manche SA v United Kingdom \& France), Partial Award, 2007, para 318. Accordingly, the UK could have "undertaken certain actions to try to induce France to comply with the obligations resting upon both respondents", but did not undertake any such actions, see Freya Baetens, 'Invoking, Establishing and Remedying State Responsibility in Mixed Multi-Party Disputes' in Christine Chinkin and Freya Baetens (eds), Sovereignty, Statehood and State Responsibility: Essays in Honour of James Crawford (CUP, 2015) p 437 .

87 Eva Steinberger, 'The WTO Treaty as a Mixed Agreement: Problems with the EC's and the EC Member States' Membership of the WTO' (2006) 17 European Journal of International Law $837, \mathrm{p} 851$.

88 See the discussion of the case in section 2.2.1. 
This indicates that while breaches of divisible shared obligations may very well result in shared responsibility, being bound to a divisible shared obligation is not enough in and of itself to give rise to shared responsibility as an automatic consequence.

\subsection{Claiming cessation and reparation for breaches of shared obligations in mixed agreements}

In those cases where breaches of shared obligations result in shared responsibility of the EU and its member states, all of them may become bound to the secondary obligations of cessation ${ }^{89}$ and reparation, ${ }^{90}$ and it becomes necessary to determine what injured parties can claim from whom. If both France and the EU are internationally responsible for breaches of the divisible shared obligation to take measure to prevent pollution, will each of them become bound to cease only part of the wrongful conduct or all of the wrongful conduct? And if the EU and its member states are internationally responsible for a breach of the indivisible shared obligation to provide 12.000 million ECU to the ACP states, will each of them become bound to repair only part of the injury or will all of them become bound to repair the whole injury?

Where these secondary obligations arise for both the EU and its member states, we are again confronted with the phenomenon of sharing obligations by the organization and its members. This section aims to show that conceiving of these secondary shared obligations as either divisible or indivisible will help determine what injured parties can claim from whom. The qualification of an obligation of cessation or reparation as divisible or indivisible differs depending on whether the EU and its members share responsibility for a single wrongful act or for multiple wrongful acts. ${ }^{91}$

\subsubsection{A shared obligation of cessation}

The obligation of cessation is geared towards restoration of the legal relationship affected by the internationally wrongful act(s) committed. It follows from Article 30 (a) ARSIWA and Article 30 (a) ARIO that the obligation to cease a wrongful act arises only for a state or international organization if the wrongful act for which it is responsible is continuing. Hence, in the case that the EU and its member states are responsible for one and the same wrongful act that is of a continuing character, an obligation to cease that act will emerge for all of them. Such a shared obligation of cessation is of an indivisible character, since

89 Article 3o(a) ARSIWA; Article 3O(a) ARIO.

90 Article 31 ARSIWA; Article 31 ARIO.

91 On these two manifestations of shared responsibility see the discussion in section 1.2. 
it obliges responsible actors to achieve a common result: the cessation of the one act for which they are all responsible.

Considering that breaches of indivisible shared obligations always results in shared responsibility for the same wrongful act, ${ }^{92}$ an obligation of cessation that arises as a result of a breach of an indivisible shared will necessarily arise for both the EU and its member state(s). For instance, if the UK and the EU breach their indivisible shared obligation to afford a certain tariff to computer equipment imported into the UK, both will become bound to an indivisible shared obligation to cease this one wrongful act. Accordingly, third parties can claim full cessation from each of them. In practice, this means that an injured party may opt to claim full cessation from all those responsible for the same wrongful act, for instance by instituting legal proceedings against all of them simultaneously. This is what happened when the US decided to institute proceedings against the EU and the UK for the alleged breach of the obligation to afford a particular tariff to imported computer equipment, ${ }^{93}$ for which it demanded cessation (which is often considered to be "the usual remedy" in the WTO dispute settlement system) $\cdot{ }^{94}$

However, claiming full cessation for a breach of an indivisible shared obligation may also take the form of directing a claim against only one of the responsible actors, asking it to ensure that the one wrongful act for which it is co-responsible is ceased. This is in accordance with Articles 47(1) ARSIWA and 48 ARIO, which stipulate that where several states or international organizations are responsible for the same wrongful act, the responsibility of each of them may be invoked in relation to that act. ${ }^{95}$ Hence, pointing to cases involving only the EU in the context of WTO dispute settlement as evidence of only the EU being internationally responsible for breaches of WTO obligations ${ }^{96}$ would seem to gloss over the fact that shared responsibility offers injured parties the choice to direct a claim against each responsible actor separately, and that each responsible actor may be asked to provide full cessation.

$92 \quad$ See section 4.3.1.

93 Certain Computer Equipment (n 38 ).

94 Petros Mavroidis, 'Remedies in the WTO Legal System: Between a Rock and a Hard Place', 11 (2000) European Journal of International Law $763-813$.

95 On this point see also Nollkaemper (n 28) p 315; Alexander Orakhelashvili, 'Division of Reparation between Responsible Entities' in James Crawford, Alain Pellet and Simon Olleson (eds), The Law of International Responsibility (OUP, 2010), p. 657.

96 See Marín Durán (n 11) pp 719-720. She critiques the proposition that WTO dispute settlement practice "has gone a long way in the direction of attributing the acts of the Member States [exclusively] to the EU". 
The choice to direct a claim against only one of the actors that share responsibility could be informed by the pragmatic consideration that one of them is particularly well-positioned to put an end to the wrongful act in question. For instance, in the Asbestos case Canada challenged only the EU - and not France - for a French asbestos decree, which Canada maintained was in breach of various obligations arising from the General Agreement on Tariffs and Trade. It appears that Canada's choice to focus only on the EU was not based on France not being bound to the obligations purportedly breached or France not being responsible for such a breach, but rather that the competence to deal with the issue at hand laid with the $\mathrm{EU}$, and an action against the EU offered a realistic prospect of a return to legality. ${ }^{97}$

Matters are different in situations where the EU and its member(s) share responsibility for multiple wrongful acts, for example if each of them fails to take measures in pursuance of limitation or reduction of greenhouse gas emissions from aviation and marine bunker fuels, which would be in breach of their divisible shared obligation arising from article 2(2) Kyoto Protocol. Provided that all of the wrongful acts are of a continuing character, an obligation of cessation will arise for both the EU and its member states. However, the nature of that shared obligation of cessation will be divisible because multiple wrongful acts have been committed, and each responsible actor becomes bound to cease its own internationally wrongful act only. ${ }^{98}$ While this means that the EU and its members states are solely obliged to cease their own wrongful conduct, this does not entail that they are in no way connected in the performance of their obligations of cessation. Depending on the influence that each of them is able to exert over the other bearers of a divisible shared obligation of cessation they may very well be required to try, with the means reasonably available to them, to induce the others to cease their wrongful conduct. ${ }^{99}$ Doing so would contribute to the main rationale underlying cessation, which is to restore the legal relationship breached and safeguard the validity and effectiveness of the underlying primary rule of international law: one of the main functions of the law of international responsibility. ${ }^{100}$ Also in this respect it is worth noting that, with a view to their close relationship, an international organization and

\footnotetext{
$97 \quad$ Nollkaemper (n 28) p 345.

98 See Pierre d'Argent, 'Reparation, Cessation, Assurances and Guarantees of Non-Repetition' in André Nollkaemper and Ilias Plakokefalos (eds), Principles of Shared Responsibility in International Law (CUP, 2014) p 215.

99 Compare the earlier discussion on the performance of divisible shared obligations, section 4.3.2 See also Principle 9(2) of the Guiding Principles on Shared Responsibility (n 17). 
its members often have a variety of means at their disposal to influence each other's conduct in order to implement such an obligation.

\subsubsection{A shared obligation to make full reparation}

In accordance with Articles 31 ARSIWA and 31 ARIO, a responsible state or organization is bound to 'make full reparation for the injury caused by the internationally wrongful act'. This obligation reflects the remedial function of the law of international responsibility, which has as one of its main goals to restore the status quo ante and place the injured party "in the position which would, in all probability, have existed if that act had not been committed."101

Unlike the obligation of cessation; the obligation of reparation does not relate to the wrongful act as such. Rather, it relates to the injury that has been caused by the wrongful act, and is dependent on a causal link between wrongful act and injury. It arises only for the state or international organization that is responsible for a wrongful act that has caused injury, and it solely obliges that state or organization to make reparation for the injury that has been caused by the wrongful act for which it is responsible.

When applied to a context in which the EU and its members are responsible for the same wrongful act, and that wrongful act causes injury, these considerations can only lead to the conclusion that all of them will become bound to an obligation to provide full reparation for the whole injury. This is due to the fact that there is only one wrongful act for which the EU and its member state(s) are responsible, which is the sole cause of the whole injury. ${ }^{102}$ This shared obligation of reparation is indivisible, as it requires its bearers to achieve a common result: the making of full reparation for the entire injury caused by their wrongful act.

For third parties injured by a breach of an indivisible shared obligation this means that full reparation can be claimed from any of the bearers of that obligation, since breaches of indivisible obligations necessarily result in shared responsibility for the same wrongful act. If, for instance, a breach of the indivisible shared obligation to provide a certain amount of financial assistance to the ACP states results in injury, full reparation can be claimed from the EU and its member states, either singly or in combination. This is confirmed by Articles 47(1) ARSIWA and 48(1) ARIO, with their above-mentioned stipulation

Factory at Chorzów, Permanent Court of International Justice, Jurisdiction, Judgment No. 8, 1927, PCIJ Series A, No. 9, p. 47; ARSIWA with commentaries (n 18) p 91. On the remedial function of the law of international responsibility see Dinah Shelton, 'Righting Wrongs: Reparations in the Articles of State Responsibility' (2002) 96 AJIL 833-856. 
that where several states or international organizations are responsible for the same wrongful act, the responsibility of each of them may be invoked in relation to that act. The only limitation imposed in the ARSIWA and ARIO is that the injured party is not entitled to 'recover, by way of compensation, more than the damage it has suffered, ${ }^{103}$ which would mean in concreto that an injured party that has already obtained full reparation for its damage from one responsible state or organization cannot direct another claim for reparation at one of the other responsible actors.

Overall, this outcome in terms of reparation resembles the notion of joint and several liability that is familiar to many domestic legal systems, ${ }^{104}$ which quite similarly encompasses that full reparation can be claimed from any of the actors that have contributed to the same damage. The rationale behind the imposition of this type of liability is in accordance with the general tort law policy of "affording the victim of the harm the maximum possible chance of having his harm properly compensated". 105

At first sight, the nature of the obligation of reparation may appear to be less straightforward in those cases where the EU and its members share responsibility as a result of breaches of a divisible shared obligation, since breaches of such obligations can (and often do) give rise to shared responsibility for multiple wrongful acts. Let us continue with the example of France and the EU failing to take the required measures to limit pollution, and assume that both of their internationally wrongful acts contribute to injury in the form of the pollution of lake Etang de Berre. Since a causal link exists between both of their wrongful acts and the injury, both of them become bound to an obligation to make reparation. But can full reparation be claimed from each of them for the whole injury, or they each repair only part of the injury?

It is submitted that as long as multiple wrongful acts contribute to the same (indivisible) injury, all of them become bound to an obligation to make full

Article 47(2) ARSIWA; Article 48(3) ARIO.

European Group on Tort Law, Principles of European Tort Law: Text and Commentary (Springer Wien New York 2005) pp. 134-138; John Noyes and Brian Smith, 'State Responsibility and the Principle of Joint and Several Liability' (1988) 13 Yale Journal of International Law 225, pp 251-254; Roger Alford, 'Apportioning Responsibility Among Joint Tortfeasors for International Law Violations' (2011) 38 Pepperdine Law Review 233, p. 241, fn. 38.

Noyes and Smith (n 104) p 254. See also The Commission on European Contract Law, Principles of European Contract Law: Part III (2003) at 64; C. von Bar and E. Clive, Principles, Definitions and Model Rules of European Private Law: Draft Common Frame of Reference (DCFR) (2009), p. 978: "in order to protect the victim of damage caused by several people $[\ldots]$ the obligation of reparation arising out of damage is solidary." 
reparation for that injury. ${ }^{106}$ Neither the ARSIWA nor the ARIO contain a provision explicitly dealing with claiming reparation in a scenario of multiple wrongful acts that contribute to injury. However, unless each of their contributions can be clearly distinguished so as to have caused an identifiable part of the injury, ${ }^{107}$ imposing the consequence of an indivisible shared obligation to make full reparation on the EU and its member state(s) is in accordance with the general rule that a state or international organization is obliged to make full reparation for the injury caused by its wrongful act. If it is unclear what part of the injury was caused by the EU or by its members, the burden to determine who caused what should not be placed on the injured third party, particularly if one takes into consideration that the protection of the rights of injured persons is one of the main functions of the law of international responsibility.

\section{5 \\ Conclusions}

In summary, this article set out to develop an obligations-based approach to the allocation of responsibility between an organization and its member states, arguing that the sharing of obligations can have relevant implications for shared responsibility. The common practice of concluding mixed agreements by the EU and its members constituted an ideal case-study in this regard, seeing that this practice regularly results in the sharing of international obligations by the EU and one or more member states, where all of them are bound to an obligation with similar normative content pertaining to the same constellation of facts. Examples include the obligation of the UK and the EU to afford a particular tariff to LAN equipment imported into UK territory, the obligation of France and the EU to strictly limit pollution from land-based sources into lake Etang de Berre on French territory and the obligation of the EU and its member states to provide 12.000 million ECU in financial assistance to the ACP states.

The idea that the sharing of international obligations in mixed agreements might have relevant implications for the allocation of responsibility is not entirely new and has been touched upon in existing literature. However, existing discussions generally proceed from an understanding of 'joint obligations'

106 See also André Nollkaemper et al (n 17) commentaries to Principle 10.

107 In relation to concurrent causes the ILC has stated that "unless some part of the injury can be shown to be severable in causal terms from that attributed to the responsible State, the latter is held responsible for all the consequences, not being too remote, of its wrongful conduct", ARSIWA with commentaries (n 18) pp. 93-94. 
that is too broad to be useful for the analysis of international responsibility. This article does not subscribe to existing approaches that either conclude that being bound to the same obligation in a mixed agreement is in and of itself enough to justify joint responsibility, or that contrariwise decide that the nature of obligations has no noteworthy role to play in determining responsibility for mixed agreements.

Rather, it has been argued that a more systematic approach to the nature of shared obligations in mixed agreements can help untangle who can be held responsible in case of a breach. On the one hand, if the EU and its members are bound to a divisible shared obligation that binds each only to its own share, whether or not a breach will give rise to shared responsibility mainly depends on the facts of each case. While shared responsibility remains a very real possibility, it is not an inevitable consequence of a breach of a divisible shared obligation, since it is possible in theory to independently breach a divisible shared obligation.

On the other hand, however, if the EU and one or more of its members are bound to an indivisible shared obligation that obliges each of them to achieve a common result, the failure to achieve that result will always give rise to the responsibility of all of them for the same internationally wrongful act. Any secondary obligation that arises as a result of this responsibility can also be qualified as an indivisible shared obligation, which means that injured third parties can claim full cessation and full reparation from any of the responsible actors. Thus, while it may be true that - as has been underlined in legal literature - being bound to the same international obligations is not sufficient to result in shared responsibility; being bound to an indivisible shared obligation is.

Accordingly, in the process of determining responsibility for breaches of obligations that are shared by the organization and its members it is essential to enquire what the obligation asks of its bearers: are they all bound to achieve a common result or is each of them bound only to its own share? Only then can it be properly evaluated whether a breach in a particular instance gives rise to the international responsibility of the $\mathrm{EU}$, one or more of its members, or a combination.

\section{Biography}

Nataša Nedeski is Assistant Professor of Public International Law at the University of Amsterdam. Her research focuses in particular on the law of international responsibility. In 2017 she successfully defended her dissertation 
entitled "Shared obligations in international law", which she is currently revising for publication with Cambridge University Press. She has been a member of the Research Project on Shared Responsibility in International Law (SHARES project) since 2011 and has contributed to the project in various forms, including as a member of the drafting committee of the Guiding Principles on Shared Responsibility in International Law, which comprise the main findings of the project and has been published in the European Journal of International Law. 